\title{
ACCEPTANCE OF ILLNESS AND SATISFACTION WITH LIFE AMONG PATIENTS WITH ARTERIAL HYPERTENSION
}

\author{
Bożena Baczewska ${ }^{1}$, Beata Kropornicka ${ }^{1}$, Joanna Sepioło, Ewa Krzyżanowska ${ }^{1}$, Cecylia Olszak ${ }^{1}$, \\ Ewa Szymczuk², Jadwiga Daniluk ${ }^{1,2}$
}

${ }^{1}$ Internal Medicine Department with the Department of Internal Nursing, Medical University of Lublin

${ }^{2}$ Department of Health, Pope John Paul II State School of Higher Education in Biała Podlaska

Baczewska B., Kropornicka B., Sepioło J., Krzyżanowska E., Olszak C., Szymczuk E., Daniluk J. (2015), Acceptance of illness and satisfaction with life among patients with arterial hypertension. Health Problems of Civilization, 3 (9), p. 31-38.

\begin{abstract}
Summary: The aim of this study was to determine and compare the degree of acceptance of the disease and the level of satisfaction with life among people with diagnosed hypertension. The research was carried out by means of a diagnostic survey. The study used the scale of AIS - Approval Illness Scale (Acceptance of Illness Scale). For measuring life satisfaction ladder Cantrill was used. It assessed satisfaction with life on a scale from 0 to 10. The study was conducted in June 2014 among the residents of Lubelskie and Świętokrzyskie voivodships. The study was anonymous. The approval of the Bioethics Committee at the Medical University of Lublin (KE-0254/176/2014) was received for carrying out the tests. The study included patients diagnosed with hypertension - total of 154 people. The study has shown the average degree of acceptance of the disease. Illness and healing therapy did not impact negatively the functioning of most respondents. The respondents described their adaptation to the limitations imposed by the disease in different degrees. The vast majority of respondents did not have any problems arising from the disease and did not abandon their favorite activities. Every third respondent with hypertension felt as being a defective person and dependent on other people. The relation between satisfaction with their own lives, and the level of acceptance of the disease was concluded in that study. The higher the degree of satisfaction with patients' lives, the higher the acceptance of illness. Studies have shown positive correlations between gender, age, place of residence, duration of illness and education, and acceptance of the disease. In contrast, there was no statistically significant association between marital status and the test subject.
\end{abstract}

Key words: acceptance, satisfaction, hypertension, illness

\section{Introduction}

Cardiovascular diseases are among the most serious health, economic and social threats of modern times (Block, Kawecka-Jaszcz 2005). One of the most common diseases is hypertension. Analysis of nationwide research dissemination and control of risk factors for heart disease in Poland (NATPOL 2011) showed that hypertension occurs in 32\% of adult Polish citizens, which means that currently there are approx. 10.5 million people in the age group above 18 years who suffer from it (Matyjaszczyk, Hoffmann et al. 2011).

In the treatment of patients with hypertension, the acceptance of the disease is a very important aspect. The degree of acceptance of the disease significantly affects the adaptation to restrictions imposed by the disease, addiction to surrounding people or the consciousness of self-worth. These factors have an impact on the subjective assessment of the quality of life, as well as determining the level of their own activities (Kaczmarczyk 2008). The acceptance of your health is a way to function properly with the disease. People who accept their illness have an optimistic way of looking into the future, they have a hope to improve their health, they are guided by trust in relation to the health facility staff and the direction or method of treatment. The acceptance is manifested by a low level of negative emotions and positive reactions in relation to one's own illness. With the increase of the acceptance of the disease, the level of adaptation to the functioning of disease also increases and the feeling of deprivation of psychological comfort decreases (Niedzielski, Humeniuk et al. 2007). The acceptance of one's health status does not reflect the resignation or weakness. It provides a consistent potential and the strength

Address for correspondence: Bożena Baczewska, Internal Medicine Department with the Department of Internal Nursing at the Medical University of Lublin, Jaczewskiego 8, 20-950 Lublin, e-mail: baczewska@o2.pl, phone: +48 817187318

Tables: 4 Figures: 1 References: 13 Full-text PDF www.hpc.edu.pl Copyright (C) Pope John Paul II State School of Higher Education in Biała Podlaska, Sidorska 95/97, 21-500 Biała Podlaska Indexation: Index Copernicus, AGR0, ProQuest, Polish Medical Bibliography, Polish Ministry of Science and Higher Education. This is an open-access article distributed under the terms of the Creative Common Attribution Non-commercial license (http://creativecommons.org/licenses/by-nc/3.0), which permits use, distribution and reproduction in any medium, provided the original works is properly cited, the use is non-commercial and is otherwise in compliance with the license. 
of people, reconciling the independent state of affairs of each other, making it very easy to continue living with the disease (Zawadzka, Kuźniewski et al. 2005). The aim of this study was to determine and compare the degree of acceptance of the disease and the level of satisfaction with life among people with diagnosed hypertension.

\section{Material}

The study was conducted in June 2014 among residents of Lubelskie and Świętokrzyskie voivodships. The study was anonymous. The approval by the Bioethics Committee at the Medical University of Lublin (KE-0254/176/2014) was received for carrying out the tests. The study included patients diagnosed with hypertension - 154 people. Detailed characteristics of the study group are presented in Table 1.

Table 1. Characteristics of the examined group with arterial hypertension

\begin{tabular}{|c|c|c|}
\hline Sex & Number of respondents & $\%$ \\
\hline Female & 83 & 53.9 \\
\hline Male & 71 & 46.1 \\
\hline Age & Number of respondents & $\%$ \\
\hline 18-25 years & 34 & 22.1 \\
\hline 26-40 years & 33 & 21.4 \\
\hline 41-60 years & 55 & 35.7 \\
\hline 61 years and more & 32 & 20.8 \\
\hline Locality & Number of respondents & $\%$ \\
\hline $\begin{array}{c}\text { Town } \\
\text { (more than } 100 \text { thousand inhabitants) }\end{array}$ & 34 & 22.1 \\
\hline $\begin{array}{c}\text { Town } \\
\text { (less than } 100 \text { thousand inhabitants) }\end{array}$ & 55 & 35.7 \\
\hline Village & 65 & 42.2 \\
\hline Education & Number of respondents & $\%$ \\
\hline Incomplete Primary & 1 & 0.6 \\
\hline Primary & 30 & 19.5 \\
\hline Vocational & 20 & 13 \\
\hline Secondary & 49 & 31.8 \\
\hline Vocational secondary & 29 & 18.8 \\
\hline Bachelor's/Engineering & 19 & 12.3 \\
\hline Higher MA & 6 & 3.9 \\
\hline Marital status & Number of respondents & $\%$ \\
\hline Miss/Single & 26 & 16.9 \\
\hline Married & 99 & 64.3 \\
\hline Divorced & 6 & 3.9 \\
\hline Widow/Widower & 8 & 5.2 \\
\hline Informal relationship & 15 & 9.7 \\
\hline Material situation & Number of respondents & $\%$ \\
\hline Very good & 10 & 6.5 \\
\hline Good & 127 & 82.5 \\
\hline Neither good, nor bad & 12 & 7.8 \\
\hline Bad & 5 & 3.2 \\
\hline Very bad & 0 & 0 \\
\hline Living & Number of respondents & $\%$ \\
\hline With family & 136 & 88.3 \\
\hline With flatmates & 12 & 7.8 \\
\hline Alone & 4 & 2.6 \\
\hline Other & 2 & 1.3 \\
\hline Duration of illness & Number of respondents & $\%$ \\
\hline $0-1$ years & 23 & 14.9 \\
\hline 1-3 years & 65 & 42.2 \\
\hline 3-5 years & 45 & 29.2 \\
\hline
\end{tabular}




\begin{tabular}{|c|c|c|}
\hline More than 5 years & 21 & 13.6 \\
\hline Blood pressure control & Number of respondents & 43.5 \\
\hline Regularly- at least one time per day & 67 & 39 \\
\hline Sometimes - when I feel bad & 60 & 16.2 \\
\hline Irregularly - as I recall & 25 & 1.3 \\
\hline I don't control my blood pressure at all & 2 & 46.8 \\
\hline Taking medicines & Number of respondents & 26 \\
\hline Regularly - as prescribed by doctor & 72 & 18.2 \\
\hline Sometimes - when I feel bad & 40 & 9.1 \\
\hline Irregularly - as I recall & 28 & 14 \\
\hline
\end{tabular}

Source: own work

The largest percentage of respondents consisted of patients aged 41-60 years (35.7\%), living in rural areas (42.2\%), with secondary education (31.8\%), married (64.3\%). The majority of respondents (82.5\%) assessed their financial situation as good. The vast majority (42.2\%) are respondents suffering from hypertension from 1 to 3 years. Regular monitoring of blood pressure at least once a day, is carried out by the largest group of respondents (43.5\%), and they also take medications on a regular basis, as recommended by the physician (46.8\%).

\section{Research methods}

The research was carried out by mean of a diagnostic survey. The study used the scale of AIS - Approval Illness Scale (Acceptance of Illness Scale), whose authors are: B.J. Felton, T.A. Revenson, G.A. Hinrichsen. Polish version of this scale has been developed by Z. Juczyński. It includes 8 phrases depicting the consequences of mediocre health. Respondent assesses each statement, analyzing them in terms of their current state, using a five scale - from 1 to 5 (1 - strongly agree, 5 - strongly disagree). By adding up the scores achieved, within a range of 8-40 points, we conclude the level of acceptance of the disease - low figure suggests the lack of it, while high - to accept the current state of health (Matyjaszek, Sierżantowicz 2010).

For measuring life satisfaction Cantrill ladder, which assessed satisfaction of life on a scale from 0 to 10 , was used. The scale includes three graphically presented ladders, and there is one point designated on each of their respective levels. Analyzing the meaning of the numbers: zero means the worst conceivable to imagine life situation, while 10 is the best. The respondents pointed satisfaction with their lives in order: before disease, now and how it is imagined in the future. It is expected that the test will determine the future life in a more favorable light than it is at present. On such basis it is concluded whether the patient has a hope to improve the health status or not. Life dissatisfaction is considered when the tested person imagines a future situation unchanged / worse than the current one (Motyka 2002).

The statistical analysis of empirical research was performed using SPSS 20.0 statistical program. Statistical analyses were performed using a ' $t$ ' Student test for independent samples (when compared to the average of two independent groups), one-way analysis of variance ANOVA intergroup scheme (in comparisons of more than two medium originating from independent samples) and the appropriate post-hoc tests; chi-square test for one attempt Pearson and Pearson correlation coefficients (as a measure of the linear relationship between quantitative variables). On the basis of the values reported by the program statistics and significance levels, a comparison was made of the significance of empirical statistics from the assumed level of alpha $=0.05$.

\section{Results}

Studies have shown different levels of acceptance of illness. The average sum of all points scored on a scale of AIS and the average values obtained from the individual theorems are presented in Table 2. 
Table 2. Values obtained from individual claims on a scale of AIS in the examined group

\begin{tabular}{|c|c|c|c|c|c|c|c|}
\hline Criterion scale AIS & average & median & minimum & maximum & $\begin{array}{c}\text { Lower } \\
\text { quartile }\end{array}$ & $\begin{array}{c}\text { Upper } \\
\text { quartile }\end{array}$ & $\begin{array}{c}\text { Standard } \\
\text { deviation }\end{array}$ \\
\hline $\begin{array}{c}\text { The sum of all points earned on the AIS } \\
\text { scale }\end{array}$ & 25.42 & 24.00 & 11.00 & 40.00 & 19.00 & 30.00 & 7.92 \\
\hline $\begin{array}{c}\text { I've got problems to adjust to the limita- } \\
\text { tions imposed by the disease }\end{array}$ & 3.1 & 3.0 & 1.0 & 5.0 & 2.0 & 4.0 & 1.1 \\
\hline $\begin{array}{c}\text { Because of my health condition I'm not } \\
\text { able to do what Ilike the most }\end{array}$ & $\mathbf{3 . 1}$ & 3.0 & 1.0 & 5.0 & 2.0 & 4.0 & 1.1 \\
\hline $\begin{array}{c}\text { Sometimes illness makes me feel not } \\
\text { needed }\end{array}$ & 3.2 & 3.0 & 1.0 & 5.0 & 2.0 & 4.0 & 1.1 \\
\hline $\begin{array}{c}\text { Health problems make me more depen- } \\
\text { dent on others than I want }\end{array}$ & $\mathbf{3 . 1}$ & 3.0 & 1.0 & 5.0 & 2.0 & 4.0 & 1.1 \\
\hline $\begin{array}{c}\text { Illness makes me a burden to my family } \\
\text { and friends }\end{array}$ & 3.2 & 3.0 & 1.0 & 5.0 & 2.0 & 4.0 & 1.2 \\
\hline $\begin{array}{c}\text { My state of health makes me feel I'm not } \\
\text { full-worth man }\end{array}$ & $\mathbf{3 . 1}$ & 3.0 & 1.0 & 5.0 & 2.0 & 4.0 & 1.3 \\
\hline $\begin{array}{c}\text { I'll never be self-sufficient enough to the } \\
\text { level I would like to be }\end{array}$ & $\mathbf{3 . 1}$ & 3.0 & 1.0 & 5.0 & 2.0 & 4.0 & 1.2 \\
\hline $\begin{array}{c}\text { I think people that spend time with me } \\
\text { very often feel embarrassed because of } \\
\text { my illness }\end{array}$ & $\mathbf{3 . 4}$ & 3.0 & 1.0 & 5.0 & 3.0 & 4.0 & 1.0 \\
\hline
\end{tabular}

Source: own work

Theories describing the consequences of hypertension in subjects in terms of constraints, lack of selfsufficiency, a sense of dependence on others or decreased self-esteem were very diverse. For the examined people it was often difficult to agree or deny those claims (score 3 on the scale).

The most often respondents disagreed with the statement that other people staying with them may make them feel embarrassed because of their disease ( $3.4 \pm 1.0$ pts.). More often they agreed with statements concerning the restrictions on self-sufficiency, a sense of dependence on others or decreased self-esteem (3.1 \pm 1.0 points).

In the group there were 17 respondents (11\%) who achieved a maximum number of points (40pkt.) That indicates that the disease in the opinion of those surveyed did not pose any restrictions. The minimum number of points was 11, which involved one respondent indicating that the disease is a consequence of bad health condition.

Studies have shown that patients accept their illness moderately. The average point value was $25.42 \pm 7.92$ points. Percentage distribution of the level of acceptance of the disease is presented in Figure 1.

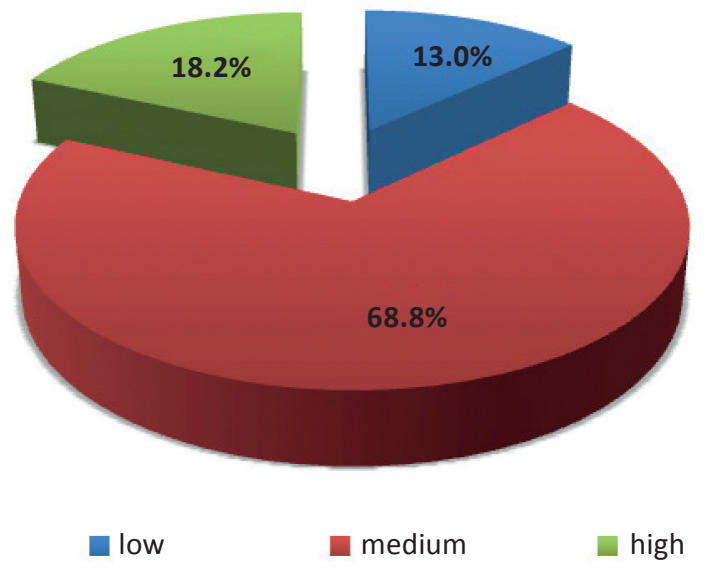

Figure 1. The level of acceptance of the disease according to the scale of AIS

Every third respondent with a hypertension says that he has a problem with adapting to the prohibitions connected with a disease, he is a burden for his family and friends, and is overly dependent on others. Even $36.4 \%$ of respondents claim that because of their health condition they are not able to do what they most like and $1 / 4$ of the test group (27.3\%) experiences the feeling of being useless. Even $40 \%$ of respondents say they would never be self-sufficient enough and 39\% of them have a low self-esteem due to their health condition. 
In the course of the data analysis, it was examined whether sociodemographic factors, such as sex, age, marital status, place of residence and duration of the disease differentiate the degree of acceptance of the disease by the study subjects. See details in the table 3 .

Table 3. The characteristics of the respondents and the level of acceptance of the disease - descriptive statistics

\begin{tabular}{|c|c|c|c|}
\hline \multicolumn{2}{|c|}{ Variable } & $\mathrm{M}$ & SD \\
\hline \multirow{2}{*}{ Sex } & woman & 24.04 & 8.248 \\
\hline & $\operatorname{man}$ & 27.03 & 7.243 \\
\hline \multirow{5}{*}{ Age } & $18-25$ years & 27.47 & 8.497 \\
\hline & $26-40$ years & 26.55 & 8.097 \\
\hline & $41-60$ years & 26.56 & 7.081 \\
\hline & 61 years and more & 20.09 & 6.326 \\
\hline & Together & 25.42 & 7.918 \\
\hline \multirow{6}{*}{ Marital status } & Single & 28.54 & 8.778 \\
\hline & Married & 25.22 & 7.604 \\
\hline & Divorced & 25.17 & 3.251 \\
\hline & Widow/widower & 19.50 & 9.813 \\
\hline & Informal relationships & 24.53 & 7.190 \\
\hline & Together & 25.42 & 7.918 \\
\hline \multirow{4}{*}{ Place of residence } & $\begin{array}{c}\text { Town - over } 100 \text { thousands } \\
\text { inhabitants }\end{array}$ & 28.82 & 8.505 \\
\hline & $\begin{array}{l}\text { Town - up to } 100 \text { thousands } \\
\text { inhabitants }\end{array}$ & 25.11 & 7.620 \\
\hline & Village & 23.89 & 7.416 \\
\hline & Together & 25.42 & 7.918 \\
\hline \multirow{6}{*}{ Education } & primary & 20.42 & 5.685 \\
\hline & vocational & 21.80 & 5.845 \\
\hline & secondary & 27.16 & 7.028 \\
\hline & secondary vocational & 26.17 & 8.984 \\
\hline & higher & 30.20 & 8.088 \\
\hline & Together & 25.42 & 7.918 \\
\hline \multirow{5}{*}{ Duration of the disease } & $0-1$ years & 26.22 & 6.403 \\
\hline & $1-3$ years & 27.60 & 8.500 \\
\hline & $3-5$ years & 23.04 & 6.509 \\
\hline & more than 5 years & 22.86 & 8.627 \\
\hline & Together & 25.42 & 7.918 \\
\hline
\end{tabular}

Source: own study

The data above show that there is a certain difference between men and women in the degree of acceptance of the disease. To verify whether it is statistically significant, Student ' $t$ ' test for independent samples was used. Test result $\mathrm{t}_{(152)}=2.372 ; \mathrm{p}<0.05$ suggests that gender differences in the degree of acceptance of the disease are statistically significant. Men present a higher degree of acceptance of the disease $(M=27 ; S D=7.24)$, than women $(M=24 ; S D=8.25)$. Cohen's d value equal to 0,38 indicates an average strength of the observed difference effect.

It was also demonstrated that there is a correlation between age, place of residence, education, duration of the disease and the degree of the acceptation of the disease by the respondents. For this purpose, we compared the average results of people of different age groups, different marital status, place of residence, education and duration of the disease. To verify whether these differences are statistically significant, we performed the univariate analysis of variance ANOVA in the intergroup scheme and multiple comparisons by tests post hoc with Bonferroni correction. The result of the analysis of variance $\mathrm{F}_{(3.150)}=6.908 ; \mathrm{p}<0.01$ means that age significantly differentiates the degree of the acceptance of the disease. The results of the multiple comparisons showed that people in the oldest age group above 60 years $(\mathrm{M}=20.1$; $\mathrm{SD}=6.33)$ display the lowest degree of acceptance of the disease in relation to the other age groups.

The result of the analysis of variance $\mathrm{F}_{(4.149)}=8.45 ; \mathrm{p}<0.01$ showed also that education significantly differentiates the degree of acceptance of the disease. People with primary education display lower degree of acceptance of the disease $(M=20.4 ; S D=5.69)$ in comparison to people with secondary, secondary vocational 
or higher education. Moreover, it was observed that people with vocational education show significantly lower degree of acceptance of the disease $(M=21.8 ; \mathrm{SD}=5.85)$ in comparison to those with higher education $(\mathrm{M}=$ 30.2; $\mathrm{SD}=8.09$ ).

The result of the analysis of variance $\mathrm{F}_{(3.150)}=4.029 ; \mathrm{p}<0.01$ means that duration of the disease differentiates the degree of acceptance of the disease. The results of the multiple comparisons show that there is a significant difference in the degree of acceptance of the disease between people suffering from hypertension from 1 to 3 years and those suffering for more than 3 years ( 3 to 5 years). People suffering from 1-3 years show significantly higher degree of acceptance of the disease $(M=27.6$; $S D=8.5)$ than those suffering from 3 to 5 years $(M=23$; $\mathrm{SD}=6.51$ ).

On the other hand, marital status does not affect the severity of acceptance of the disease, which is supported by the results of the analysis of variance $\mathrm{F}_{(4.149)}=2.262$.

Satisfaction with one's own life is a factor that may significantly influence the acceptance of the disease. Cantril's Ladder was used to examine the above-mentioned element. Average values of the individual answers are shown in table 4.

Table 4. Satisfaction of life of the respondents based on the modified Catril's Ladder

\begin{tabular}{|c|c|c|c|c|c|c|c|}
\hline Criterion & Average & Median & Minimum & Maximum & $\begin{array}{c}\text { Lower } \\
\text { quartile }\end{array}$ & $\begin{array}{c}\text { Upper } \\
\text { quartile }\end{array}$ & $\begin{array}{c}\text { Standard } \\
\text { deviation }\end{array}$ \\
\hline Before the disease & 7.1 & 7.0 & 3.0 & 10.0 & 6.0 & 9.0 & 1.8 \\
\hline Now & 5.5 & 5.5 & 0.0 & 10.0 & 4.0 & 7.0 & 2.0 \\
\hline In 5 years & 5.2 & 5.0 & 0.0 & 10.0 & 4.0 & 7.0 & 2.2 \\
\hline
\end{tabular}

Source: own study

Satisfaction of respondents with their own lives in the period before the disease fluctuated around an average level of $7( \pm 1.8)$. The same respondents with reference to the future placed their satisfaction on average at the level of $5( \pm 1.8)$.

In the period before the disease was diagnosed, 121 of respondents $(78.6 \%)$ were satisfied with their lives, whereas lack of satisfaction was demonstrated by 33 of respondents (21.4\%). In the present time, both the number of respondents satisfied with life and those dissatisfied were at the level of $50 \%$. It seems to be significant that respondents predict their future in 5 years as worse. Most of the respondents (52.6\%) predict lack of satisfaction with their lives. It may indicate lack of hope for health improvement.

In the course of the analysis, also the connections between satisfaction with life and acceptance of the disease was verified. For this purpose, average scores of respondents in terms of the degree of acceptance of the disease with the self-assessment of their lives were compared.

It was demonstrated that there is a certain difference in terms of the acceptance of the disease between people with high and low life satisfaction. To verify whether it is statistically significant, we used Student ' $\mathrm{t}$ ' test for independents samples. The test results $t_{(75)}=3.524 ; p<0.01$ show that the intergroup difference in terms of the disease acceptance is statistically significant. People with high life satisfaction show significantly higher degree of disease acceptance ( $M=28.67 ; \mathrm{SD}=8.04)$ in comparison to people with low satisfaction with their own lives $(M=21.55 ; S D=8.05)$. The value of Cohen's $d$ coefficient 0.81 indicates a great strength of the observed difference effect.

\section{Discussion}

Hypertension is a disease of affluence, which is strongly connected with improper lifestyle. Nowadays, in Poland it is a cause of $50 \%$ of the total number of deaths, hospitalization and permanent inability to work. Hypertension causes patients to experience many negative emotions, limitations and complications. This state means for the patient the need to struggle with difficulties connected with symptoms or treatment throughout their whole life. An important factor allowing people to adjust to living with a disease is its acceptance (WronaPolańska 2000).

On the basis of the research, it was concluded that most of people were characterized by an average disease acceptance. The disease was accepted in a high degree by $18.18 \%$ of respondents, average by $68.83 \%$ and low by $12.99 \%$. It can be assumed that such a distribution of factors is caused by a different advancement of the disease in respondents.

The research showed that most of the patients with hypertension did not have to change their professional and non-professional activity due to diagnosis (43.5\%), and the disease did not affect negatively their social life (51.9\%). The vast majority of patients did not report sleeping problems $(73.4 \%)$ and the level of physical 
activity did not change following the diagnosis (33.1\%). It is also worth mentioning that every third respondent (33.8\%) does not agree with an opinion that the pharmacological agents he receives are ineffective or adversely affect his health condition. Fogari and Zoppi (2004) in their research conclude that the disease and the medical treatment did not cause deterioration of functioning in most of the respondents, which is significantly improving the quality of lives of patients with hypertension, and thus substantially makes it easier to accept the disease.

According to our own research, a significant proportion of respondents feel they are dependent on others due to the disease (31.8\%). Patients' self-sufficiency is also at the same level as almost $40 \%$ of respondents consider themselves to be not self-sufficient enough, whereas $37 \%$ of patients are of the opposite view. The research also shows that $39 \%$ of respondents has a low self-esteem due to their health condition and the same percentage of patients have a different view. The above-mentioned factors are important components predisposing to disease acceptance, which is confirmed by researches conducted by Niedzielski et al. (2007).

The conducted research also revealed the connection between satisfaction with life and disease acceptance. People who are satisfied with their lives demonstrated a significantly higher degree of disease acceptance (28.67 $\pm 8.04)$, than respondents dissatisfied with their lives $(21.55 \pm 8.05)$.

Analysis of the results of our own research showed that sociodemographic factors, such as sex, age, place of residence and the duration of the disease, influence the degree of disease acceptance.

On the basis of the obtained data, it is visible than men show a significantly higher acceptance for their health condition $(27 \pm 7.24)$, than women $(24 \pm 8.25)$. It is also confirmed by the research conducted by Kwaśniewska and Drygas (2005), in which it was proven that women in case of a chronic disease, such as hypertension, define their quality of life as low. The observed phenomenon is most likely caused by the occurrence of the socalled affect labelling. Likewise, a study by Woźnicka et al. (2008) demonstrated that men assess the quality of their lives more positively in comparison to women. This applies both to respondents with complicated and uncomplicated hypertension. Particularly noteworthy is the fact that in a group of patients with uncomplicated hypertension, men judge their health condition to be good, whereas women's assessment fluctuates between good and sufficient.

According to the research conducted by Klocek et al. (2005), the age of respondents is another factor differentiating the degree of acceptance in a group of chronically ill patients, e.g. with hypertension, especially after the age of 75. This is mainly due to the reported problems, especially in the case of pain or movement restrictions. Our own research showed a similar relationship. People from the oldest age group, after the age of 60 (20.1 \pm 6.33$)$, demonstrated a significantly lower degree of disease acceptance in comparison to other groups. After analyzing the results, we can assume that age is a factor that lowers the acceptance of the disease.

Researches show that the place of residence is significant in acceptance of living with hypertension. Inhabitants of big cities demonstrate a much higher degree of disease acceptance (28.8 \pm 8.5$)$ in comparison to villagers $(23.9 \pm 7.41)$. Therefore, we can assume that people living in larger urban centres can more easily understand their own health condition and adapt to a new, difficult situation.

The results of our own research suggest that the assumption regarding the impact of marital status on the degree of acceptance in patients with hypertension should be rejected.

On the basis of the conducted research, it can be observed that the duration of the disease is a significant factor influencing its acceptance. Comparing the results, we can conclude that there is a substantial discrepancy between the degree of disease acceptance in a group of people suffering from 1 to 3 years and those that suffer from hypertension for more than 3 years, but less than 5. Patients forming the first group show a significantly higher degree of disease acceptance (27.6 \pm 8.5 ) in comparison to respondents from the second group. Despite the lack of materials confirming the connection between the duration of a disease and its acceptance, we can assume that patients suffering from hypertension for a shorter period of time have numerous problems with adjusting to their new health situation and with the acceptance of the disease. In case of people suffering for more than 5 years, a chronic disease, such as hypertension, can lead to many frustrations, dissatisfaction with life, depressed mood, decrease in energy, stronger emotional reactions, which results in lowering of the acceptance of their own health condition. It is confirmed by a research conducted by Coelho R. et al. (1999).

\section{Conclusions}

1. The respondents accept their disease to a medium degree.

2. The disease and medical treatment did not affect negatively the functioning of most of the respondents.

3. The respondents define their adaptation to the limitations imposed by the disease in varying degrees. The vast majority of respondents have no problems resulting from the disease and do not resign from their favourite activities. 
4. Every third respondent with a hypertension feels defective and dependent on others.

5. There is a correlation between satisfaction with one's owns life and the degree of disease acceptance. The greater the satisfaction with life of the patients is, the higher the acceptance of the disease.

6. There have been demonstrated positive correlations between sex, age, place of residence, the duration of the disease and education on the one side, and the disease acceptance on the other. On the other hand, a statistically significant correlation between marital status and the examined issue has not been found.

\section{References:}

1. Coelho R., Santos A., Ribeiro L., Gama G., Prata J., Barros H., Polónia J. (1999), Differences in behavior profile between normotensive subjects and patients with white-coat and sustained hypertension. Journal of Psychosomatic Research, 46, p. 15-27.

2. Fogari R., Zoppi A. (2004), Effect of antihypertensive agents on quality of life in the elderly. Drugs Aging, 21, p. 377-393.

3. Kaczmarczyk M. (2008), Poziom akceptacji choroby osób starszych zamieszkujących w różnych środowiskach. Studia Medyczne, 12, p. 29-33.

4. Klocek M., Kawecka-Jaszcz K. (2003), Jakość życia chorych z pierwotnym nadciśnieniem tętniczym. Część I: Wpływ czynników socjodemograficznych. Przegląd Lekarski, 60, p. 92-100.

5. Klocek M., Kawecka-Jaszcz K. (2005), Walsartan - skuteczność przeciwnadciśnieniowa, tolerancja i wpływ na jakość życia. Nadciśnienie Tętnicze, 9, p. 415-424.

6. Kwaśniewska M., Drygas W. (2005), Jakość życia u osób obciążonych czynnikami ryzyka choroby niedokrwiennej serca. Przegląd Lekarski, 62, p. 863-870.

7. Matyjaszczyk P., Hoffmann K., Brył W. (2011), Epidemiologia wybranych czynników ryzyka chorób układu krążenia. Przegląd Kardiodiabetologiczny, 6, p. 255-262.

8. Matyjaszek U., Sierżantowicz R., Mariak Z. (2010), Akceptacja własnej choroby przez pacjentów z jaskrą. Polski Merkuriusz Lekarski, 163, p. 37-41.

9. Motyka M. (2002), Psychoterapia elementarna w opiece ogólnomedycznej. Publishing House UJ Kraków, p. 20-27.

10. Niedzielski A., Humeniuk E., Błazkia P., Federuk D. (2007), Stopień akceptacji choroby w wybranych chorobach przewlekłych. Wiadomości Lekarskie, 60(5-6), p. 224-227.

11. Woźnicka L., Posadzy-Małaczyńska A., Leśkiewicz G., Głuszek J. (2008), Ocena jakości życia pacjentów chorujących na nadciśnienie tętnicze według ankiety SF-36. Nadciśnienie Tętnicze, 12(2), p. 109-117.

12. Wrona-Polańska H. (2000), Człowiek wobec poważnej choroby somatycznej - próba syntezy. Sztuka Leczenia, 6 , p. 77-84.

13. Zawadzka B., Kuźniewski M., Sułowicz W. (2005), Charakterystyka chorych leczonych przewlekłymi dializami w ramach koncepcji adaptacji. Cz. I: Charakter adaptacji psychofizjologicznej pacjentów leczonych przewlekłymi dializami. Nef. Dial. Pol.; 9: 32-35.

Submitted: 22.10 .2014

Accepted: 28.05.2015 